Article

\title{
Capturing Dioclea Reflexa Seed Bioactives on Halloysite Nanotubes and pH Dependent Release of Cargo against Breast (MCF-7) Cancers In Vitro
}

\author{
Srinivasan Balapangu 1,2 ${ }^{1,}$ Emmanuel Nyankson ${ }^{3}$, Bernard O. Asimeng ${ }^{1}$, Richard Asiamah ${ }^{1}$, \\ Patrick K. Arthur ${ }^{2,4}$ and Elvis K. Tiburu 1,2,* \\ 1 Department of Biomedical Engineering, University of Ghana, Legon LG27, Ghana; \\ ssbalapangu@ug.edu.gh (S.B.); boasimeng@ug.edu.gh (B.O.A.); rasiamah001@st.ug.edu.gh (R.A.) \\ 2 West Africa Center for Cell Biology of Infectious Pathogens (WACCBIP), University of Ghana, Legon LG54, \\ Ghana; parthur14@gmail.com \\ 3 Department of Material Science \& Engineering, University of Ghana, Legon LG27, Ghana; \\ enyankson@ug.edu.gh \\ 4 Department of Biochemistry, Cell \& Molecular Biology, University of Ghana, Legon LG54, Ghana \\ * Correspondence: etiburu@ug.edu.gh; Tel.: +233-559-585-194
}

check for updates

Citation: Balapangu, S.; Nyankson, E.; Asimeng, B.O.; Asiamah, R.; Arthur, P.K.; Tiburu, E.K. Capturing Dioclea Reflexa Seed Bioactives on Halloysite Nanotubes and $\mathrm{pH}$ Dependent Release of Cargo against Breast (MCF-7) Cancers In vitro. Separations 2021, 8, 26. https:// doi.org/10.3390/separations8030026

Academic Editor: Marcello Locatelli

Received: 23 December 2020

Accepted: 14 February 2021

Published: 27 February 2021

Publisher's Note: MDPI stays neutral with regard to jurisdictional claims in published maps and institutional affiliations.

Copyright: (C) 2021 by the authors. Licensee MDPI, Basel, Switzerland. This article is an open access article distributed under the terms and conditions of the Creative Commons Attribution (CC BY) license (https:/ / creativecommons.org/licenses/by/ $4.0 /)$.

\begin{abstract}
In this work, optimization parameters were developed to capture plant metabolites from Dioclea Reflexa (DR) seed ex-tracts onto halloysites nanotubes (HNTs). A one-step pool of the crude extracts at neutral $\mathrm{pH}$ from the HNT lumen failed to elicit a reduction in breast cancer, Michigan Cancer Foundation-7 (MCF-7) cell viability. However, the $\mathrm{pH}$-dependent elution of metabolites revealed that the acidic $\mathrm{pH}$ samples exhibited profound antiproliferative effects on the cancer cells compared to the basic $\mathrm{pH}$ metabolites using both trypan blue dye exclusion assay and 3-(4,5dimethylthiazol-2-yl)-2,5-diphenyl-2H-tetrazolium bromide (MTT) viability test. $\mathrm{pH} 5.2$ samples demonstrated by half-maximal inhibitory concentration (IC50) of $0.8 \mathrm{mg}$ and a cyclic voltammetry oxidation peak potential and current of $234 \mathrm{mV}$ and $0.45 \mu \mathrm{A}$, respectively. This indicates that the cancer cells death could be attributed to membrane polarization/depolarization effects of the sample. Fluorescence-activated cell sorting (FACS) studies confirmed that the plant metabolites affected breast cancer apoptotic signaling pathways of cell death. The studies proved that plant metabolites could be captured using simplified screening procedures for rapid drug discovery purposes. Such procedures, however, would require the integration of affordable analytical tools to test and isolate individual metabolites. Our approach could be an important strategy to create a library and database of bioactive plant metabolites based on $\mathrm{pH}$ values.
\end{abstract}

Keywords: halloysite nanotubes; cyclic voltammetry; polarization/depolarization Dioclea Reflexa; plant metabolites; anticancer metabolites

\section{Introduction}

Traditional herbal medicine practices continue to be inseparable in the lives of many people in the world, including the inhabitants of sub-Sahara Africa (sSA), due to the impact of plant metabolites for treating several diseases [1-3]. Over the years, the global acceptance of herbal medicines in homes, as well as health clinics, has resulted in the growth of the herbal products market in most countries in the subregion. However, there are still challenges with understanding mechanisms of action due to the lack of standardized procedures to rapidly prepare plant metabolites to meet pharmacological criteria [4-6]. This gap, especially in the subregion, has elevated the research community enthusiasm in pursuing cheap and affordable functional materials to facilitate the development of simple and effective separation technologies that have similar or even better performance efficiencies than the traditional and more expensive technologies. Such easy-to-use technologies 
will facilitate the capture, release, and compilation of plant metabolites in a library and database to support further scientific research in the field of plant medicine $[7,8]$.

Recently, solid-phase microextraction (SPME) technology has been developed using $\mathrm{TiO} 2$ nanotube arrays in situ on Ti wires for selective removal of organic compounds [9]. However, this technology exhibits some drawbacks, including fragility, which limits longevity. Halloysites nanotubes (HNTs) are natural tubules of aluminosilicate minerals composed of different proportions of aluminum, silicon, hydrogen, and oxygen, often with the chemical formula $\mathrm{Al}_{2} \mathrm{Si}_{2} \mathrm{O}_{5}(\mathrm{OH})_{4} \cdot \mathrm{nH}_{2} \mathrm{O}[10,11]$. They are empty cylinders with widths of about 100 nanometers and consist of two structures: the anhydrous structure with an interlayer dispersing of approximately $7 \AA$ and the hydrated structure with an augmented interlayer dividing of $10 \AA$, due to the presence of water in the lamellar spaces [12-14]. In each layer of the halloysite nanotubes (HNTs), the siloxane $(\mathrm{SiOH})$ groups are found on the outer surface, while the aluminol $(\mathrm{AlOH})$ groups are situated on the inner surfaces, making the outer and inner surfaces have different charges. The positive charge of the internal lumen is a consequence of protonation of the $\mathrm{AlOH}$ group at low $\mathrm{pH}$, whereas the $\mathrm{SiOH}$ groups has overall negative charge due to the coordination of the atoms. These unique properties of HNTs have made it possible for it to be used in various biomedical applications, such as the development of biohybrid materials for health applications [15]. The charge disparity has drawn interest from the research community, whereby overall negatively charged proteins taken above their isoelectric points were mostly loaded into the positively charged nanotube lumen [16]. Therefore, in a pool of organic compounds, HNTs can facilitate the formation of a transient bond between selected bioactive compounds and the $\mathrm{AlOH}$ or $\mathrm{SiOH}$ as a function of $\mathrm{pH}$ conditions and can be very effective as a nano drug carrier for different applications [17-22]. The loading efficiency is influenced by the charge characteristics of the active agents, as well as vacuum pressure [23].

The species Dioclea Reflexa (DR) hook belong to leguminoase plants, which include legume, pea, and the bean families. There are certain classes of compounds in Dioclea reflexa (DR) that have clinical usefulness in both temperate and tropical regions [24-26]. Extract of DR seed has been shown to boost hematological parameters and antioxidant activities which protect the kidney and blood from oxidative and related injuries under acute and chronic toxicological challenges [1,2,24,25,27-31]. In addition, the aqueous extract of the seeds produces $100 \%$ mortality in third stage mosquito larvae of Aedes aegypti. The seed is a potential food source which contains around $14 \%$ protein, $8 \%$ fats, and $58 \%$ carbohydrates [26]. Though these metabolites in the pool continue to show promise in disease treatment, there is very limited data in the literature of the properties of single isolates and their medicinal relevance, albeit due to the difficulties in pursuing systematic separation of the complex mixtures in a single separation method. Thus, the current work describes the use of a simplified method to systematically isolate bioactive compounds from extracted complex mixtures from DR and test their inhibitory effects on breast Michigan Cancer Foundation-7 (MCF-7) cells. The rationale is that the larger surface area coupled with the differential polarity of the lumen and the surface of the HNTs will be sufficient to bind selectively with the plant metabolites in the crude extracts of DR. The authors hypothesized that: (1) the $\mathrm{pH}$ dependent elution of the plant metabolites can identify therapeutic bioactive compounds against cancer cells and that (2) specific HNT could isolate structurally and functionally related metabolites from complex mixtures in a single step. The evidence of the entrapped species onto the HNTs was monitored using X-ray diffractometry (XRD) and Fourier transform infrared spectroscopy (FTIR) to determine the degree of aluminol $(\mathrm{AlOH})$ and the siloxane $(\mathrm{SiOH})$ groups modification since these two functional groups will be key sites for bioactive compounds interaction. pH-dependent eluted samples have been tested on breast (MCF-7) cancer cell lines to investigate both their inhibitory and the mechanism using cyclic voltammetry and flow cytometry analyses [32-35]. The results are reported here and show evidence of differential inhibitory effects of the bioactive compounds from the various $\mathrm{pH}$ conditions. 


\section{Materials and Methods}

\subsection{Materials}

$\mathrm{N}$,N-dimethyl sulfonamide, sodium hydroxide $(\mathrm{NaOH},>99 \%)$, acetic acid $\left(\mathrm{CH}_{3} \mathrm{COOH}\right.$, $>99 \%)$, sulfuric acid $\left(\mathrm{H}_{2} \mathrm{SO}_{4},>99 \%\right)$, hydrochloric acid $(\mathrm{HCl})$, and propidium iodide were purchased from Fisher Scientific, Altrincham, UK. Samples of natural halloysite (cat. no. 685445 ) were purchased from Sigma Aldrich, St. Louis, USA. All chemicals were analytical grade and were, therefore, used without further purification. Breast (MCF-7) cancer cells (HTB-22) were purchased from American Type Culture Collection (ATCC) (Manassas, VA, USA) and maintained in Dulbecco's modified eagle medium (DMEM-F12) complete media supplemented with $10 \%$ fetal bovine serum (FBS), minimum essential medium (MEM) nonessential amino acids, gentamicin, and $10 \mu \mathrm{g} / \mathrm{mL}$ insulin in a $5 \% \mathrm{CO}_{2}$ incubator at $37^{\circ} \mathrm{C}$. All culturing media were obtained from ATCC (Manassas, VA). RNase A from Sigma Aldrich, St. Louis, MO, USA.

\subsection{Methods}

2.2.1. Loading and $\mathrm{pH}$-Dependent Release of DR Metabolites

A $5 \mathrm{~g}$ quantity of Dioclea Reflexa (DR) seed powder was suspended in $30 \mathrm{~mL}$ of $70 \%$ ethanol ( $\mathrm{pH} 7.4$ ) for $24 \mathrm{~h}$ to extract the plant metabolites [6]. A volume of $30 \mathrm{~mL}$ of the supernatant was used for the immobilization using 120 to 1320 milligram quantities in intervals of $120 \mathrm{mg} / \mathrm{mL}$ of halloysite nanotubes(HNTs). A UV-Vis spectrophotometer (Shimadzu UV /Vis 1601 spectrophotometer, Shimadzu Corporation, Tokyo, Japan) was used to determine the concentration of the crude extracts before and after loading onto the halloysites nanotubes. A standard curve was then constructed to determine the amount of entrapped bioactive compounds from the DR seed extracts.

The percentage loading capacity, LC was obtained from Equation (1):

$$
\mathrm{LC}=\mathrm{M}_{\mathrm{m}} / \mathrm{M}_{\mathrm{h}} \times 100
$$

where $M_{m}$ and $M_{h}$ are the masses of the entrapped metabolites and the amount of halloysites used for the entrapment, respectively.

The loaded HNTs were weighed and stored at $20^{\circ} \mathrm{C}$, and the entrapped metabolites were released using a buffer of $\mathrm{pH}(4.1-9.6)$ for $24 \mathrm{~h}$.

\subsubsection{Characterization of HNTs and DR Loaded HNTs}

FTIR spectra of empty halloysites nanotubes (HNTs) and Dioclea Reflexa (DR) loaded HNTs were recorded with a Nicolet MAGNA-IR 750 Spectrometer (Nicolet Instrument Co., Madison, WI, USA). The spectra were recorded from 500 to $4000 \mathrm{~cm}^{-1}$ wavenumber with 16 scans and spectral resolution of $4 \mathrm{~cm}^{-1}$.

XRD (Empyrean, Malvern Panalytical B.V, Almelo, The Netherlands) of the HNTs and loaded HNTs were performed using a Pan Analytical diffractometer with $\mathrm{CuK} \alpha$ radiation. A $2 \theta$ scan was performed from 5 to $35^{\circ}$ in steps of $0.05^{\circ}$, with a tube voltage of $45 \mathrm{kV}$ and a current of $40 \mathrm{~mA}$.

The Thermogravimetric Analyzer (TGA) (Q600 SDT, TA Instruments, Brussels, Belgium) analysis of the HNT and HNT loaded with the DR extract was conducted using Pyris 1 TGA equipment. The analysis was conducted in $\mathrm{N}_{2}$ atmosphere at a heating rate of $20{ }^{\circ} \mathrm{C} / \mathrm{min}$.

\subsubsection{Culturing and Cyclic Voltammetry Analysis of MCF-7 Breast Cancer Cell Lines}

MCF-7 cells (HTB-22) were grown and maintained in DMEM-F12 supplemented media. Media was changed every $2-3$ days, and cells were passaged at $65-80 \%$ confluence. The cells were harvested after complete rinsing with $0.25 \%(w / v)$ Trypsin and $0.53 \mathrm{mM}$ Ethylenediamine tetra acetic acid (EDTA) solution to remove all traces of fetal bovine serum, which contains trypsin inhibitor. A volume of 2.0 to $3.0 \mathrm{~mL}$ of Trypsin-EDTA solution was added to the flask, and the cells were observed under an inverted microscope. 
A volume of 6.0 to $8.0 \mathrm{~mL}$ of complete growth medium was used to aspirate the cells, and the suspension was centrifuged at $125 \mathrm{mg}$ for 5 to $10 \mathrm{~min}$. After re-suspension, cell density of $5.6 \times 10^{6}$ was obtained. The inhibitory effects (expressed as Percentage Activity, (PA)) of the metabolites concentration of $2 \mathrm{mg} / \mathrm{mL}$ on the cells was determined using Equation (2). $M_{o}$ is the initial concentration of the extracts, $M_{p h}$ is the concentration of the extracts at particular $\mathrm{pH}$.

$$
\mathrm{PA}=\frac{\mathrm{M}_{\mathrm{o}}-\mathrm{Mph}}{\mathrm{M}_{\mathrm{o}}} \times 100
$$

A stock solution of $2 \mathrm{mg} / \mathrm{mL}$ of the metabolites from $\mathrm{pH} \sim 5.2$ was prepared for electrochemical detection studies using cyclic voltammetry under steady-state conditions. The electrochemical detection was carried out using A CheapStat potentiostat device (IO Rodeo, Pasadena, CA, USA) connected to interdigitated gold electrodes (IDEs)/Microelectrodes (Metrohm, DropSens Llanera, Asturias, Spain). A volume of $5 \mu \mathrm{L}$ of cells of cell density of $2.3 \times 10^{6}$ cells / well was suspended in $0.1 \mathrm{mM}$ Phosphate Buffer Saline (PBS), and the metabolite was also dispensed in $0.002 \mathrm{mM}$ dimethyl sulfoxide (DMSO). The samples were deposited on the active electrode for cyclic voltammetry measurements. The voltammograms were obtained using a potential range from 690 to $970 \mathrm{mV}$ at a scan rate of $10 \mathrm{mVs}^{-1}$. Cell viability studies was conducted using trypan blue assay and confirmed by MTT assay. The MTT assay protocol is based on the conversion of water soluble MTT (3-(4,5-dimethylthiazol-2-yl)-2,5-diphenyltetrazolium bromide) compound to an insoluble formazan product by the viable cells. [36-40].

\section{Results}

\subsection{Characterization of HNT and loaded HNT using XRD, TGA, and FTIR}

In an effort to determine the presence of trapped compounds in the HNT, preparations were subjected to analysis using XRD, TGA, and FTIR techniques. In Figure 1a (red), the characteristic $2^{\circ}$ peak positions of HNT occur at 11.7, 20.5, 24.8, 37.5, and 62.2, representing (001), (110), (011), (131), and (331) crystallographic planes, respectively. After immobilization of the DR extracts on the nanotubes, there was dramatic reduction of the peak intensities at the same $2^{\circ}$ positions, indicating that the resulting structure of the composite material (HNT with DR) is more amorphous than that of HNT. This is expected since the metabolites from the DR are mostly amorphous in nature. The absence of additional peaks aside the characteristic peaks of HNTs after loading with DR depicts the amount of DR loaded was less than $5 \%$ by weight of the HNTs. Since the metabolite may be amorphous, it is likely that the peaks of the HNTs overshadowed the amorphous peaks of the extract, and, as a result, no clearly defined XRD peaks were found. The bioactive constituents were eluted with $70 \%$ ethanol and resulted in HNTs signature peaks, as shown in Figure 1a (blue). The characteristic peak intensities reverted to those observed in the control, implying that the reduced intensities were due to the plant extract.

The changes in the signatures peak intensities of the halloysite nanotubes (HNTs) was monitored using FTIR spectroscopy, as shown in Figure 1b. The FTIR spectra revealed all the functional groups present in the empty HNTs (black). Six major peaks were identified in the HNT. The inner Al-OH and outer Si-OH groups have characteristic stretching peaks at 3622 and $3694 \mathrm{~cm}^{-1}$, respectively. Bending vibrations of $\mathrm{Al}-\mathrm{OH}$ and $\mathrm{Si}-\mathrm{OH}$ revealed absorption peaks at $902 \mathrm{~cm}^{-1}$. In addition, the uneven stretching vibrations of the Si-OH bond gave a strong absorption peak at 995 and $1118 \mathrm{~cm}^{-1}$. In addition, the deformation vibration of the interlayer water molecules of the HNT was observed at $1647 \mathrm{~cm}^{-1}$. There was a significant increase of the transmission peak intensities after immobilization of the DR extracts on the HNTs (blue). Four distinct additional peaks were observed in the FTIR spectra of the halloysite nanotubes loaded with the DR extract, as can be seen in Figure $1 \mathrm{~b}$. These peaks were also present in the FTIR spectra of the DR extract. The peak observed at $1744 \mathrm{~cm}^{-1}$ is due to the $\mathrm{C}=\mathrm{O}$ stretching, while the peak observed at $1460 \mathrm{~cm}^{-1}$ represents the symmetric $\mathrm{C}-\mathrm{H}$ vibration. The symmetric and asymmetric vibrations of $\mathrm{CH}_{2}$ were represented by the peaks observed at 2923 and $2854 \mathrm{~cm}^{-1}$ [41]. Since the peaks present 
in the HNT and DR extract were observed in the HNT loaded with DR extract sample, it depicts that the HNT was indeed loaded with the DR extract.

To further confirm that the DR extract was loaded into the HNT, TGA analysis of the raw HNTs and HNT loaded with the DR extract was conducted. This analysis also helped in estimating the amount of DR extract loaded into the HNTs. The TGA results is presented in Figure 1c. Two distinct decompositions were observed at approximately $60^{\circ} \mathrm{C}$ and $450{ }^{\circ} \mathrm{C}$. The weight losses observed at $60^{\circ} \mathrm{C}$ and $450{ }^{\circ} \mathrm{C}$ can be attributed to the decomposition of the water molecules absorbed onto the HNT surface and the dehydroxylation of the HNTs, respectively. Considering the HNT loaded with the DR extract, a significant mass loss was observed between $25-85^{\circ} \mathrm{C}$. This mass loss can be attributed to the decomposition of the $70 \%$ ethanol solution used in the loading process. The HNT loaded with the DR extract contained some moisture when the TGA analysis was being conducted. In addition to this observed decomposition, another gradual decomposition was observed from approximately $240-370{ }^{\circ} \mathrm{C}$. This gradual decomposition can be attributed to the extract. This implies that the HNT loaded with the DR extract indeed contained the DR extract. The amount of the loaded DR extract was estimated to be approximately $5.18 \mathrm{wt} . \%$.

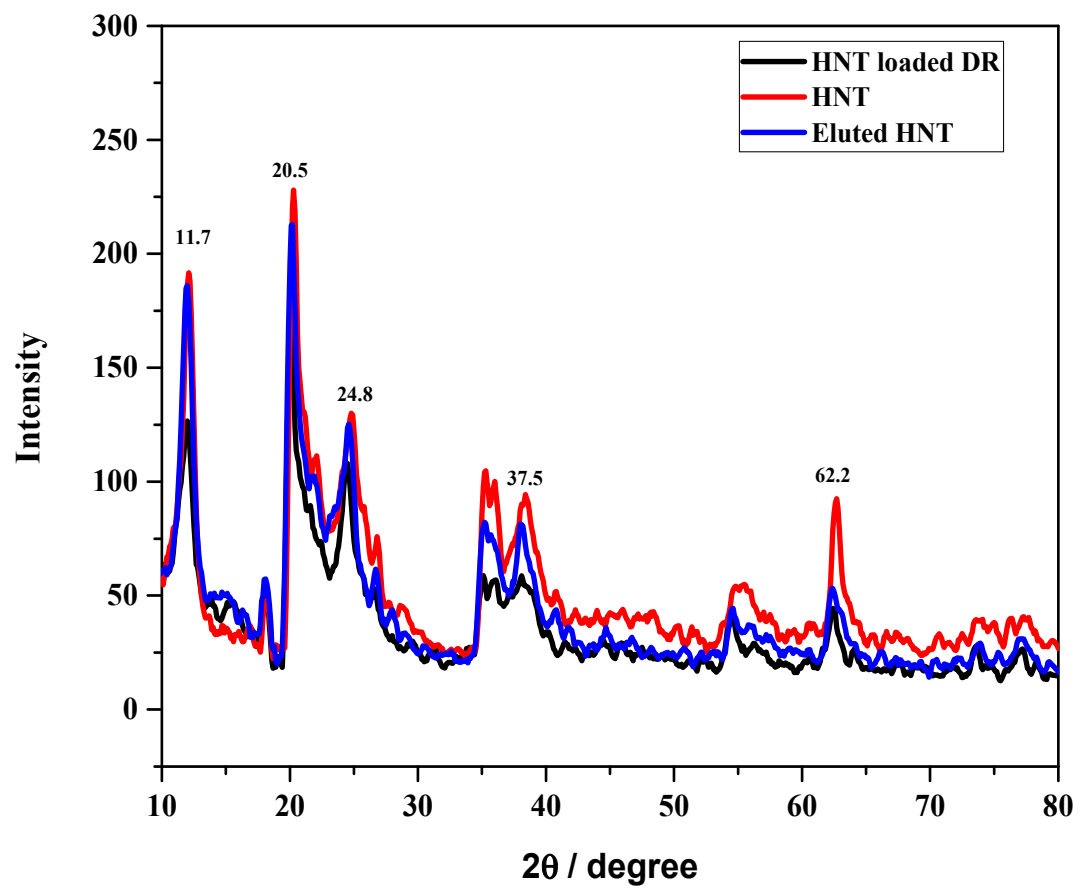

(a)

Figure 1. Cont. 


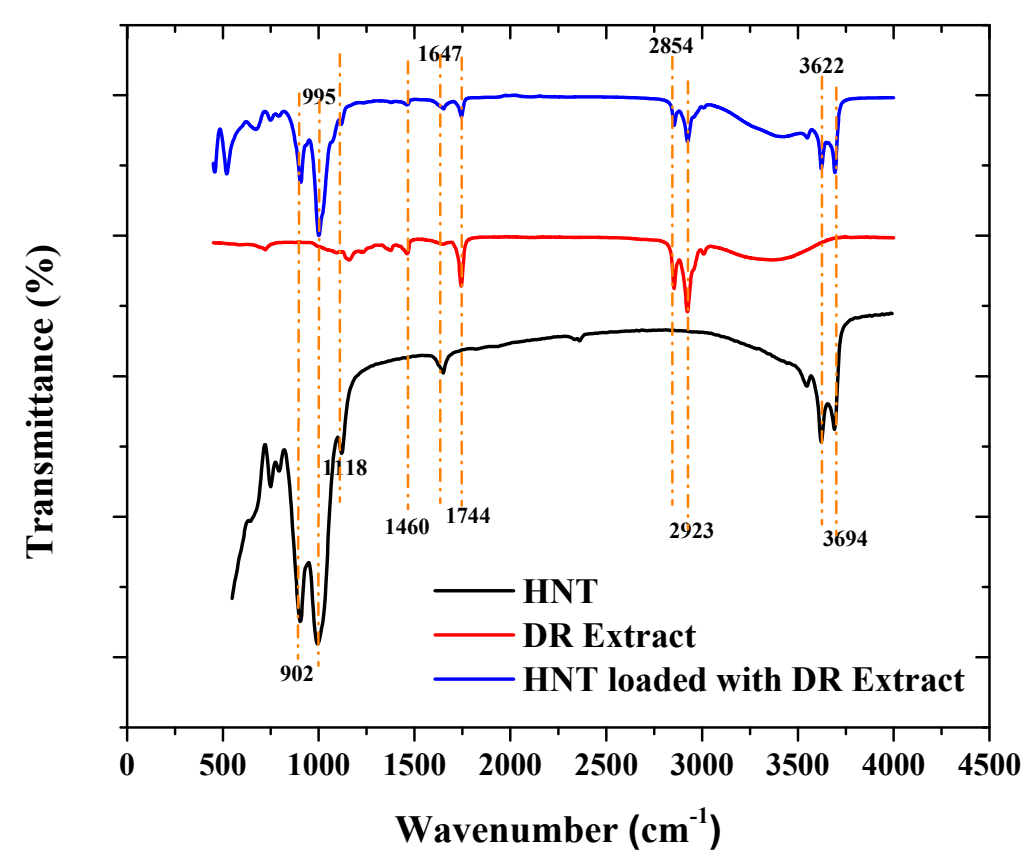

(b)

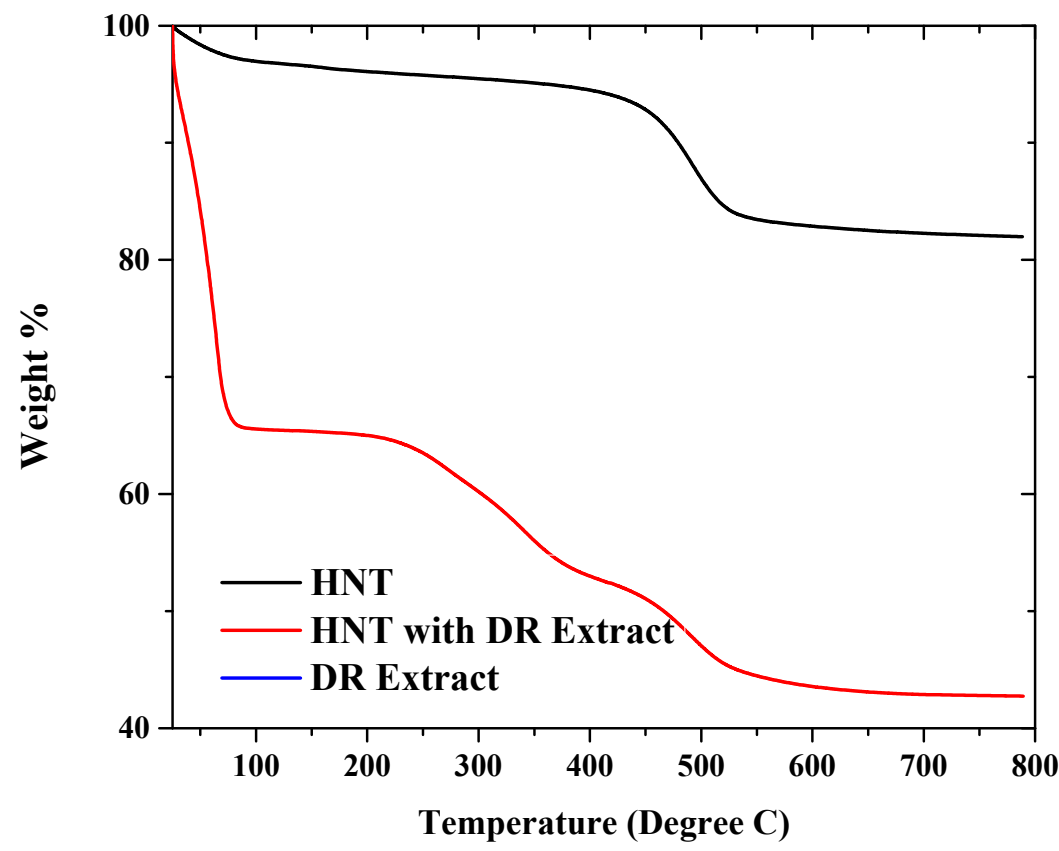

(c)

Figure 1. (a) X-ray diffractometry (XRD) spectra of halloysites nanotubes (HNT) and HNT loaded with the Dioclea Reflexa (DR) extract. (b) Fourier transform infrared (FTIR) spectra of HNTs and loaded HNTs with plant metabolites. (c) TGA of HNT and HNT loaded with DR extract.

3.1.1. Optimization of Parameters to Increase Metabolites Immobilization onto HNTs

Concentration dependent analysis of the bioactive compounds entrapped on the HNT using varied concentrations of the nanotubes is displayed in Figure 2a. It was observed that the maximum extractable bioactive compounds at the loading range from 720 to $1080 \mathrm{mg}$ 
of HNTs using DR concentration of $0.2 \mathrm{~g} / \mathrm{mL}$ in a total volume of $30 \mathrm{~mL}$ of crude extract solution was about $14-19 \%$.
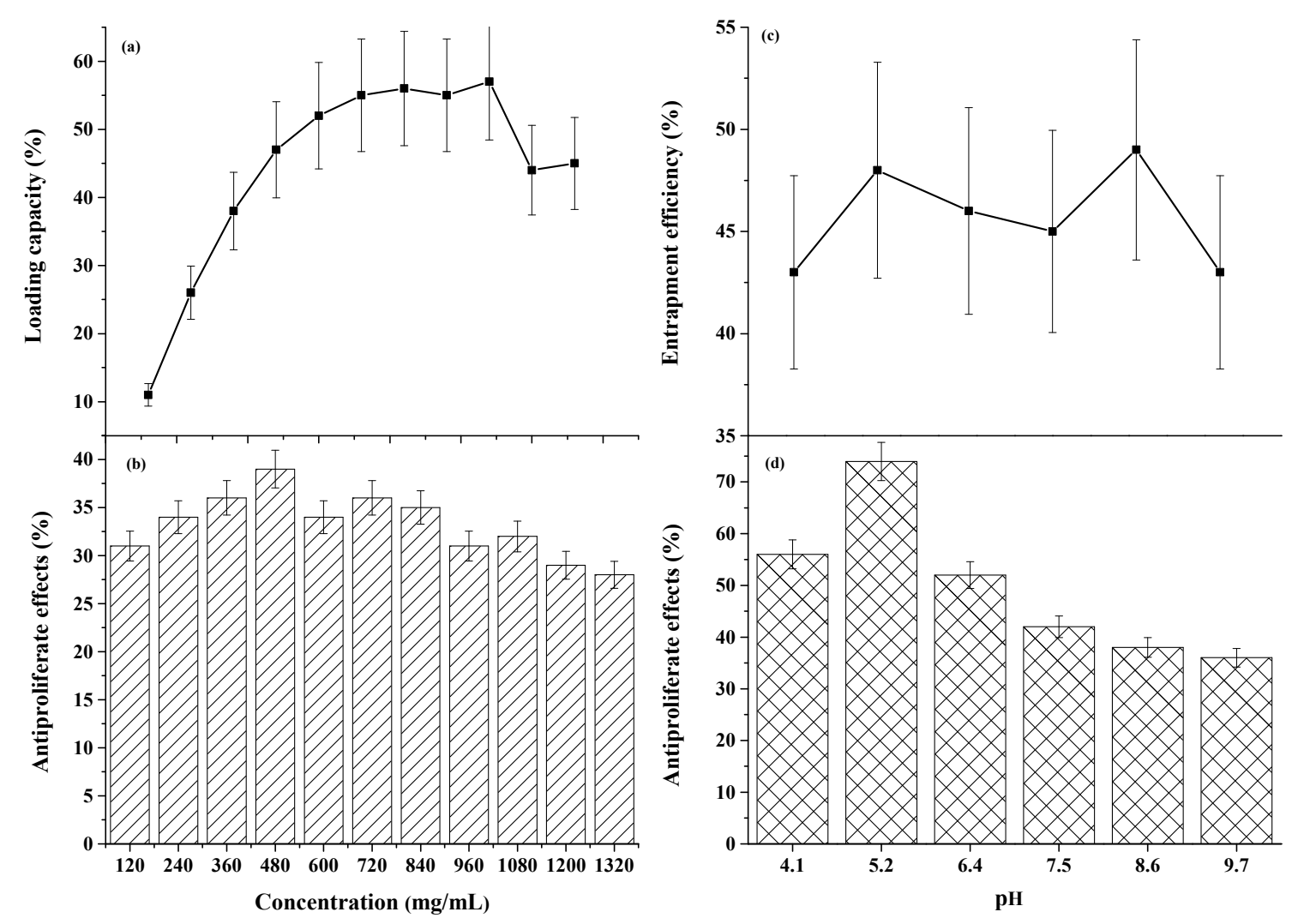

Figure 2. Optimization of the conditions for DR entrapment using HNTs. (a) The relative amount in percentage of entrapped bioactive compounds $(\mathrm{mg} / \mathrm{mL})$ using 5 grams bed volume of HNTs. The release was conducted for 2 days to ensure all the bound molecules were completely released from the lumen of the HNT. (b)MTT assay for MCF-7 cell viability analysis of the entrapped bioactive compounds from the various crude extracts using $2 \mathrm{mg} / \mathrm{mL}$. (c) The effects of buffer $\mathrm{pH}$ on the release of the immobilized bioactive compounds. (d) The relative activity of $\mathrm{pH}$ dependent bioactive compounds on MCF-7 cell viability using $2 \mathrm{mg} / \mathrm{mL}$ concentrations.

Figure 2 showed the inhibitory effects of $2 \mathrm{mg} / \mathrm{mL}$ of the entrapped metabolites on breast (MCF-7) cancer cell lines at cell density $6.3 \times 106$. It was observed that the crude extracts from the HNTs lumen did not show significant increase in percent antiproliferative effects on the MCF-7 cells, as indicative by the statistically insignificant variations in cell viability.

\subsubsection{PH-Dependent Elution of the Metabolites from HNTs}

The $\mathrm{pH}$-dependent release of the bioactive compounds is displayed in Figure 2. The results revealed $\mathrm{pH}$ effect on the release of the bioactive compounds from HNTs was the same based on the profile exhibited in Figure 2. To investigate the inhibitory effects of the $\mathrm{pH}$ eluted samples, a $2 \mathrm{mg} / \mathrm{mL}$ was prepared from all the samples and tested on the cancer cells, as shown in Figure 2d. All the samples tested demonstrated some level of percent inhibition with the extract from $\mathrm{pH}(\sim 5.2$ and $\sim 9.6)$, revealing the highest and the lowest degree of percent antiproliferative effects of 74 and 36, respectively. The $\mathrm{IC}_{50}$ in Table 1 of the water and ethanol extracts, as well as those of the $\mathrm{pH}$ dependent eluted samples, were determined to confirm the trend of inhibition demonstrated in Figure 2. The inhibitory effects of the bioactive compounds eluted at acidic $\mathrm{pH}$ had much lower $\mathrm{IC}_{50}$ of $0.8-1.6$, with $\mathrm{pH} 5.2$ revealing the lowest $\mathrm{IC}_{50}$, which indicated the metabolites from that fraction are more potent to the cells, as shown in Table 1. 
Table 1. $\mathrm{IC}_{50}$ values of the extracts eluted at different $\mathrm{pH}$ conditions, all measured in milligram, and quantities of the seed extract.

\begin{tabular}{ccc}
\hline Treatment & \multicolumn{2}{c}{ Normalized } \\
\hline Sample/Dry Extract & IC $_{\mathbf{5 0}}(\mathbf{m g})$ & R Squared Value \\
\hline Water & 33.3 & 0.959 \\
Ethanol & 1.6 & 0.991 \\
pH 4.1 & 1.4 & 0.967 \\
pH 5.2 & 0.8 & 0.998 \\
pH 6.4 & 1.6 & 0.975 \\
pH7.4 & 1.9 & 0.983 \\
pH 8.1 & 2.3 & 0.948 \\
pH 9.6 & 3.1 & 0.994 \\
\hline
\end{tabular}

\subsubsection{Response of the MC-7 Cells in the Presence of the Metabolites}

The influence of the metabolites from $\mathrm{pH} ~ 5.2$ on breast (MCF-7) cancer cells viability was monitored with cyclic voltammetry (CV). Figure 3 showed the oxidation peak potential and current fluctuations as the response variables when the cells were treated with the metabolites at different $\mathrm{pH}$. In Figure 3A, the empty electrode did not exhibit electrochemical response, as indicated by a horizontal line, whereas the treated cells samples showed a quasi-reversible $\mathrm{CV}$ profile. The voltage- $\mathrm{pH}$ at the same concentration of metabolites described an inverse correlation between metabolite concentration and oxidation peak potential, revealing a Pearson correlation coefficient (R2) 98.64, as in Figure 3B. However, the peak current correlation exhibited a triangular wave pattern as a function of metabolite concentration, as shown in Figure 3C.

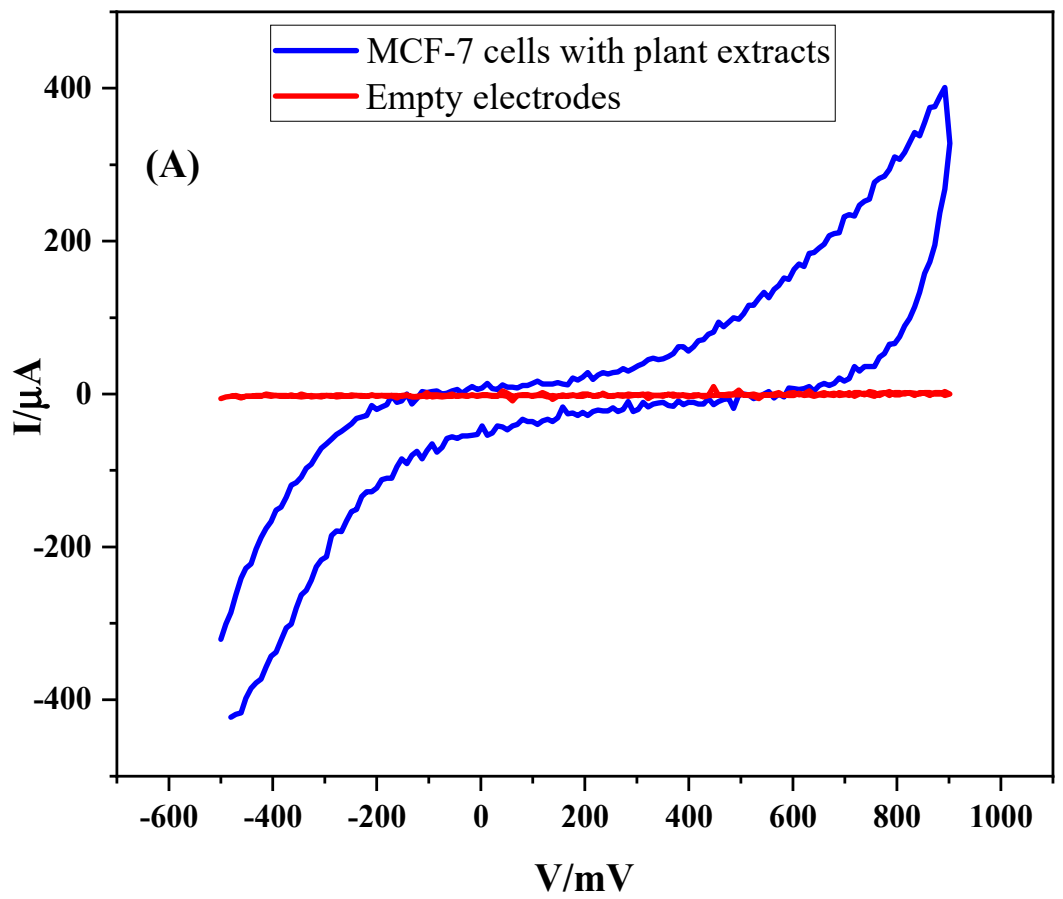

Figure 3. Cont. 


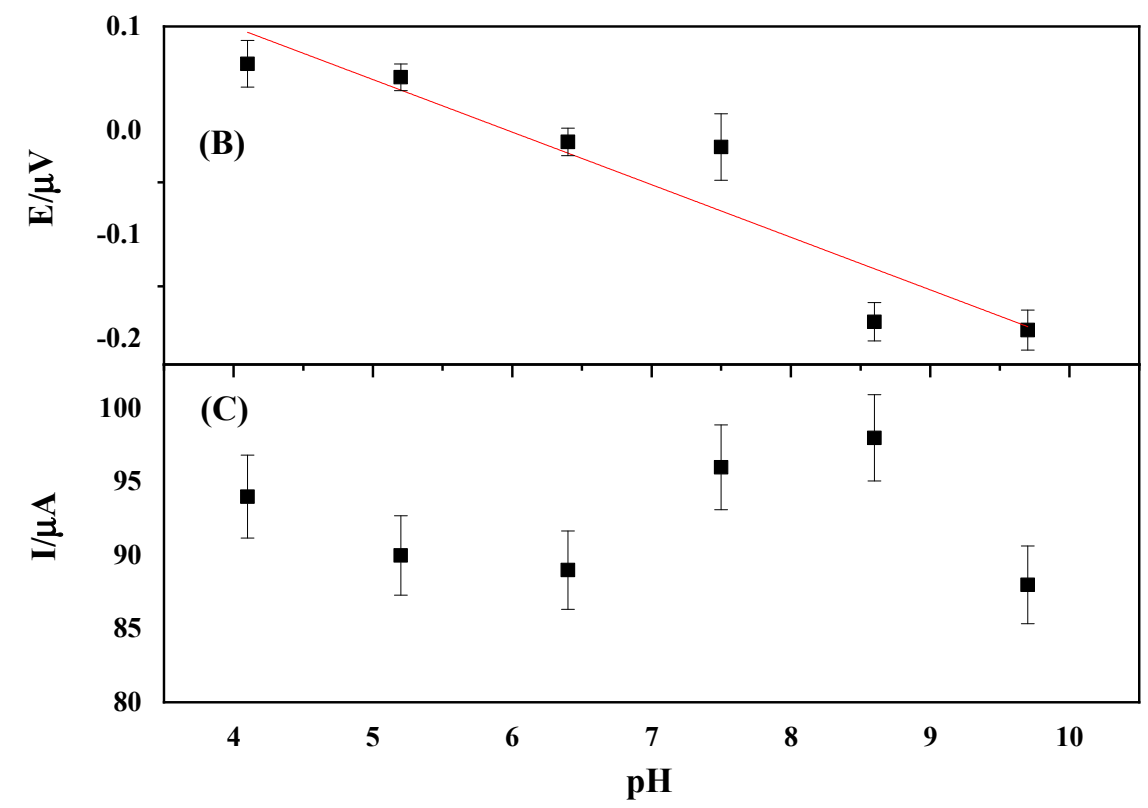

Figure 3. (A) Effects of the bioactive compounds from the $\mathrm{pH} \sim 5.2$ on the depolarization potential of the MCF-7 cells. $(\mathrm{B}, \mathrm{C})$ The influence of the voltage on current of the MCF-7 cells as a function of $\mathrm{pH}$. The cyclic voltammogram measurements conditions were: Scanning from $690 \mathrm{mV}$ to $970 \mathrm{mV}$ at a scan rate of $10 \mathrm{mV} \mathrm{s}^{-1}$. MCF-7 cancer cell viability studies of the bioactive compounds extracted at pH 5.2 at cell concentration of $1 \times 10^{6}$ cells $/$ well.

\subsubsection{Flow Cytometry Analysis of the Active Metabolites on Cell Behavior}

Flow cytometry analysis (BD LSRFortessa X-20, BD Biosciences, Le Pont de Claix, France) was conducted to investigate the mechanism of inhibition of the breast (MC-7) cancer cells by the metabolites obtained from $\mathrm{pH} \sim 5.2$ and the results compared with a commercially available drug (Curcumin), as shown in Figure 4. The quadrants referred to the cell condition, as displayed in the flow cytometry results, after a $48 \mathrm{~h}$ incubation time frame. The symbols Q1, Q2, Q3, and Q4 on the graph were used to represent debris, dead cells, live cells, and apoptotic cells, respectively. The conditions of the cells before and after treatment with the drug, as well as the metabolites, and the results compared with the control indicated that the curcumin showed dramatic cell death at concentration of $0.02 \mathrm{mg} / \mathrm{mL}$ without going through significant apoptosis. Conversely, the metabolites showed some level of cell death but with significant apoptotic effects. 
(a)

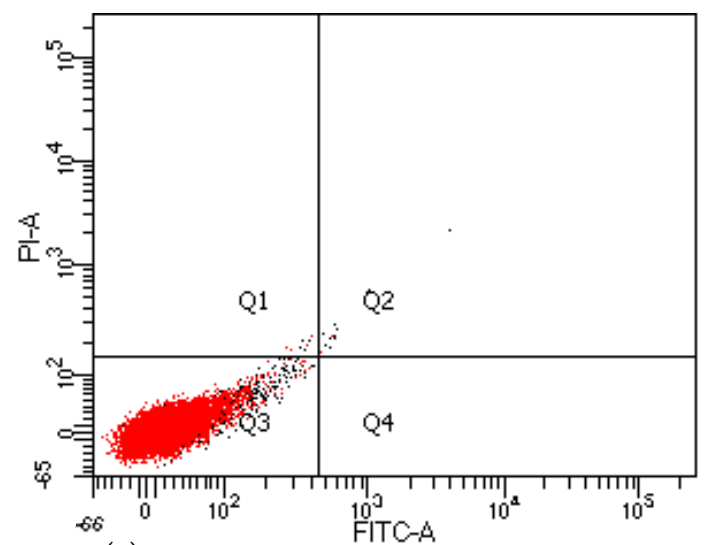

(c)

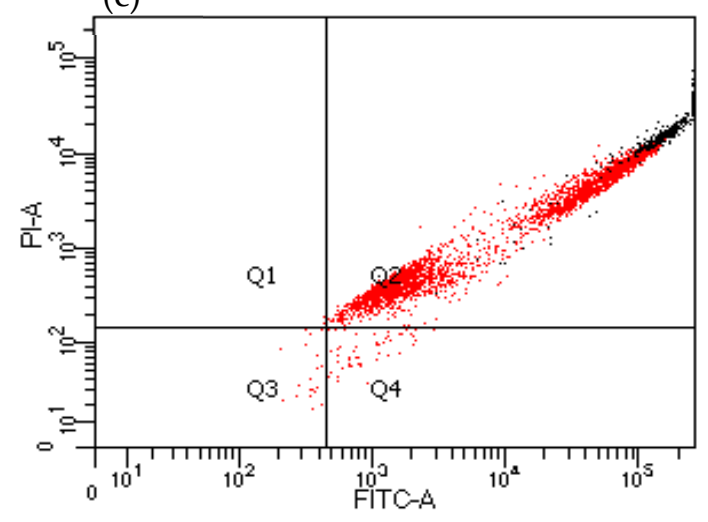

(b)

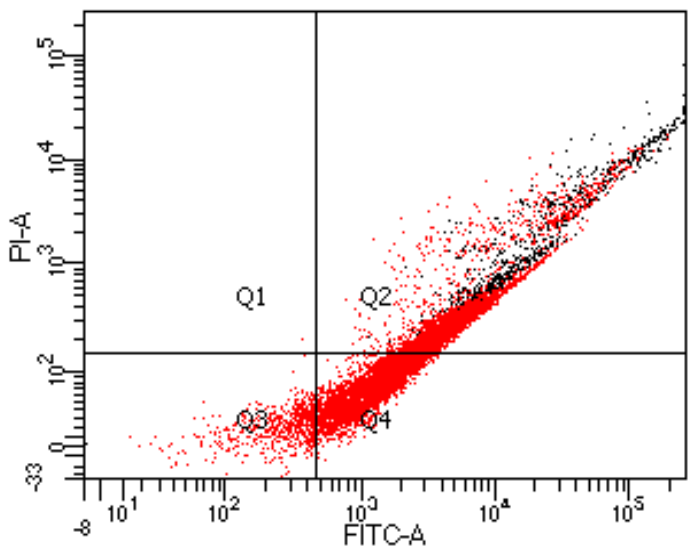

Figure 4. Fluorescence activated cell sorting (FACS) analysis of the inhibitory effects of breast (MCF-7) cancer cells using bioactive extracts at pH 5.2 (best IC50 concentration). The results were compared to the inhibitory effects of a commerciallyavailable cancer drug, cucurmin. (a) Untreated cells, (b) cells treated with extract, and (c) cells treated with curcumin, all at cell concentration of $1 \times 10^{6}$ cells/well.

\section{Discussion}

The current work seeks to propose aluminosilicate minerals, HNTs, to be used to entrap plant metabolites for biomedical applications. The biomimetic material has been used for various health applications due to its unique natural design consisting of empty cylinders with widths of about 100 nanometers. The XRD, FTIR, and TGA results clearly imply that the HNTs was loaded with the extracted crude DR. The reduction of XRD peak intensities imply the crystallinity of the loaded HNT is reduced due to the immobilization of bioactive compounds on the HNT and this observation is in conformity to literature which indicates that crystallinity of HNT decreases when bioactive compounds complex with the material [42]. The DR extract is expected to be amorphous, hence, the observed reduction in the peak intensities of the HNT loaded with the DR extract. The FTIR spectra transmission fingerprints of the HNT and HNT loaded with DR extract confirmed that the HNTs was loaded with the HNTS. There was no observed shift in the peaks of the HNT after loading. This implies that the functional groups present in the DR extract may not have interacted chemically with the functional groups present in HNTs. If there was any chemical interaction, then it is likely the interaction was not pronounced enough to cause any significant/observable shift in the peaks. The reversal of the peak intensities back to that of the empty tubules indicates that the bioactive compounds entrapped in the lumen of the HNT are transient and reversible. Thus, the plant metabolites can easily be released using buffer with different $\mathrm{pH}$ values, as was reflected in the FTIR and XRD spectra. The TGA results further confirmed that the HNT was indeed loaded with the DR extract. The decomposition of the DR extract in the HNT loaded DR was observed between $240-370{ }^{\circ} \mathrm{C}$, 
and the amount of the DR extract loaded into the HNT was estimated to be approximately $5.1 \mathrm{wt} . \%$.

The captured bioactive compounds fail to show significant bioactivity when the crude extracts from the optimization parameters are tested on model cancer cell lines. Though literature reveals DR contains flavonoids, phenolics compounds, alkaloids, and antioxidants, as confirmed by UV studies and other analytical characterizations, our studies show the cells are not compromised in their cell viability in the presence of the metabolites $[6,26,43]$. However, further studies are required to carry out careful analysis on the extracts to confirm the presence of these metabolites. Nonetheless, the rationale of the current study is to develop a simple procedure to capture metabolites mixtures for further characterization.

We used $\mathrm{pH}$-dependent elution of the bioactive compounds from the HNTs to further validate the activity of the captured metabolites on cell death. $\mathrm{HNTs}$ have $\mathrm{SiOH}$ and $\mathrm{AlOH}$ groups, which are found on the outer surface and the inner surface, making the outer and inner surfaces have different charges, respectively. The charge disparity has drawn interest from the research community, whereby overall negatively charged proteins taken above their isoelectric points are mostly loaded into the positively charged tube's lumen [16]. Thus, depending on the $\mathrm{pH}$ conditions, aluminol $(\mathrm{AlOH})$ and the siloxane $(\mathrm{SiOH})$ groups can either be protonated or deprotonated, leading to different affinities towards certain macromolecules and organic compounds. Our hypothesis here was that partially positive metabolites will be weakly attracted to the $\mathrm{SiOH}$ groups, whereas negatively charged metabolites will prefer the latter. The $\mathrm{pH}$ dependent release of the metabolites from the HNTs are not statistically different after determining the amount in milligram quantities and expressing the entrapment efficiency as a percentage value. However, when tested against the breast (MCF-7) cancer cell lines, the acidic $\mathrm{pH}$ elution demonstrates significant anti-proliferative activity against the cancer cell lines compared to the basic $\mathrm{pH}$ metabolites. The most profound activity is found in the $\mathrm{pH} 5.2$, which is supported by IC50 calculated values.

Polarization and depolarization are attributes associated with mitochondrial dysfunction in most cancer cells and can be used to inform the mechanism of cell death [44]. In this work, cyclic voltammetry measurements are used to probe the extent of polarization and depolarization by relating the voltage to current surge using electrochemical detection methods. The results reveal that the metabolites exhibit quasi-reversible redox behavior and concentration dependent reduction in the applied voltage [45]. The currents also show a triangular modulation with a rise in oxidation current at lower $\mathrm{pH}$, follow by another rise beyond acidic $\mathrm{pH}$ and further reduction in the strongly basic $\mathrm{pH}$ conditions. Metabolites from the $\mathrm{pH} 5.2$ extract require a higher voltage application to generate the minimum amount of current in the cells, indicating that cell membrane polarization in the presence of the metabolite is achieved. The extracts from $\mathrm{pH} 7.4$ and $\mathrm{pH} 8.1$, even though they give higher IC50 values, the voltage required to initiate cell depolarization is at a minimum. Nonetheless, the highlights of the current studies are that the metabolites can cause cell death through a polarization/depolarization mechanism, as documented by other researchers in the literature [46].

Flow cytometer-based analysis shows that the metabolites exhibit dose-dependent apoptosis of MCF-7 cells. It is noted that exposure of $2 \mathrm{mg} / \mathrm{mL}$ concentrations of the metabolites leads to a greater than two-fold increase in apoptosis in comparison to the untreated cells. Curcumin is a well-known polyphenol obtained from Curcuma longa, and it is widely used for its anti-oxidative and anti-cancerous application. Curcumin effects on the breast cancer cells are also investigated and compared to the results from the metabolites. It is observed that curcumin improves cell death significantly, without going through the apoptotic phase, indicating the synergistic effect could be developed when both metabolites and curcumin are used to treat cancer. 


\section{Conclusions}

In this work, it is demonstrated that optimization of parameters for Dioclea Reflexa (DR) extracts immobilization on HNT and subsequent releasing the cargo based on $\mathrm{pH}$ could find important lead metabolites for discovering druggable entities without going through complex analytical techniques. Such simplified methods will need additional modified analytical tools to expediate the drug discovery pipeline. The work also intend to provide plant metabolites database with fundamental information on herbal medicine isolation and characterization to serve the scientific community in future studies of herbal medicine.

Author Contributions: Conceptualization, E.K.T. and S.B.; methodology, B.O.A. and E.N.; software, P.K.A., R.A., and S.B.; validation, E.K.T., and P.K.A.; formal analysis, E.K.T.; investigation, E.K.T.; resources, P.K.A.; funding acquisition, E.K.T. and P.K.A. All authors have read and agreed to the published version of the manuscript.

Funding: This research was funded by Wellcome Trust, grant number 107755/Z/15/Z.

Acknowledgments: We would like to thank Lily Paemka (Cancer Biology Laboratory) at the West African Center for Cell Biology of Infectious Pathogens (WACCBIP) for support in providing the facilities and technical assistants for the work. We also thank Solomon Katu and Shadrack O. Aboagye for assisting the team conducting the experiments in the Department of Biomedical engineering.

Conflicts of Interest: The authors declare no conflict of interest.

\section{References}

1. Saqib, Z.; Mahmood, A.; Malik, R.N.; Syed, J.H.; Ahmad, T. Indigenous knowledge of medicinal plants in Kotli Sattian, Rawalpindi district, Pakistan. J. Ethnopharmacol. 2014, 151, 820-828. [CrossRef]

2. Pal, D.; Mandal, M.; Senthilkumar, G.; Padhiari, A. Antibacterial activity of Cuscuta reflexa stem and Corchorus olitorius seed. Fitoterapia 2006, 77, 589-591. [CrossRef]

3. Bhandari, P.; Sendri, N.; Devidas, S.B. Dammarane triterpenoid glycosides in Bacopa monnieri: A review on chemical diversity and bioactivity. Phytochemistry 2020, 172, 112276. [CrossRef]

4. Ge, Y.-W.; Wang, S.-M.; Zhang, L.-Y. Label-free small molecule probe and target discovery of traditional Chinese medicine. Zhongguo Zhong Yao Za Zhi 2019, 44, 4152-4157. [PubMed]

5. Benattia, F.K.; Arrar, Z.; Dergal, F.; Khabbal, Y. Pharmaco-Analytical Study and Phytochemical Profile of Hydroethanolic Extract of Algerian Prickly Pear (Opuntia ficus-indica.L). Curr. Pharm. Biotechnol. 2019, 20, 696-706. [CrossRef]

6. Arthur, P.K.; Yeboah, A.B.; Issah, I.; Balapangu, S.; Kwofie, S.K.; Asimeng, B.O.; Foster, E.J.; Tiburu, E.K. Electrochemical Response of Saccharomyces cerevisiae Corresponds to Cell Viability upon Exposure to Dioclea reflexa Seed Extracts and Antifungal Drugs. Biosensor 2019, 9, 45. [CrossRef] [PubMed]

7. Bittner, M.; Schenk, R.; Springer, A.; Melzig, M.F. Economical, Plain, and Rapid Authentication of Actaea racemosa L. (syn. Cimicifuga racemosa, Black Cohosh) Herbal Raw Material by Resilient RP-PDA-HPLC and Chemometric Analysis. Phytochem. Anal. 2016, 27, 318-325. [CrossRef]

8. Wang, H.; Zhao, X.; Wang, S.; Tao, S.; Haibo, W.; Wang, Y. Fabrication of enzyme-immobilized halloysite nanotubes for affinity enrichment of lipase inhibitors from complex mixtures. J. Chromatogr. A 2015, 1392, 20-27. [CrossRef] [PubMed]

9. Liu, H.; Wang, D.; Ji, L.; Li, J.; Liu, S.; Liu, X.; Jiang, S. A novel TiO2 nanotube array/Ti wire incorporated solid-phase microextraction fiber with high strength, efficiency and selectivity. J. Chromatogr. A 2010, 1217, 1898-1903. [CrossRef]

10. Gianni, E.; Avgoustakis, K.; Papoulis, D. Kaolinite group minerals: Applications in cancer diagnosis and treatment. Eur. J. Pharm. Biopharm. 2020, 154, 359-376. [CrossRef]

11. Saif, M.J.; Asif, H.M.; Naveed, M. PROPERTIES AND MODIFICATION METHODS OF HALLOYSITE NANOTUBES: A STATE-OF-THE-ART REVIEW. J. Chil. Chem. Soc. 2018, 63, 4109-4125. [CrossRef]

12. Park, K.; Lee, J.; Chang, J.H.; Hwang, K.H.; Lee, Y. Characterization of Surface-Modified Halloysite Nanotubes by Thermal Treatment Under Reducing Atmosphere. J. Nanosci. Nanotechnol. 2020, 20, 4221-4226. [CrossRef]

13. Tas, C.E.; Ozbulut, E.B.S.; Ceven, O.F.; Tas, B.A.; Unal, S.; Unal, H. Purification and Sorting of Halloysite Nanotubes into Homogeneous, Agglomeration-Free Fractions by Polydopamine Functionalization. ACS Omega 2020, 5, 17962-17972. [CrossRef] [PubMed]

14. Jang, S.H.; Jang, S.R.; Lee, G.M.; Ryu, J.H.; Park, S.I.; Park, N.H. Halloysite Nanocapsules Containing Thyme Essential Oil: Preparation, Characterization, and Application in Packaging Materials. J. Food Sci. 2017, 82, 2113-2120. [CrossRef]

15. Lisuzzo, L.; Wicklein, B.; Lo Dico, G.; Lazzara, G.; Del Real, G.; Aranda, P.; Ruiz-Hitzky, E. Functional biohybrid materials based on halloysite, sepiolite and cellulose nanofibers for health applications. Dalton Trans. 2020, 49, 3830-3840. [CrossRef] 
16. Tully, J.; Yendluri, R.; Lvov, Y. Halloysite Clay Nanotubes for Enzyme Immobilization. Biomacromolecules 2016, 17, 615-621. [CrossRef]

17. Barman, M.; Mahmood, S.; Augustine, R.; Hasan, A.; Thomas, S.; Ghosal, K. Natural halloysite nanotubes /chitosan based bio-nanocomposite for delivering norfloxacin, an anti-microbial agent in sustained release manner. Int. J. Biol. Macromol. 2020, 162, 1849-1861. [CrossRef] [PubMed]

18. Bonifacio, M.A.; Gentile, P.; Ferreira, A.M.; Cometa, S.; De Giglio, E. Insight into halloysite nanotubes-loaded gellan gum hydrogels for soft tissue engineering applications. Carbohydr. Polym. 2017, 163, 280-291. [CrossRef]

19. Bottino, M.C.; Yassen, G.H.; Platt, J.A.; Labban, N.; Windsor, L.J.; Spolnik, K.J.; Bressiani, A.H.A. A novel three-dimensional scaffold for regenerative endodontics: materials and biological characterizations. J. Tissue Eng. Regen. Med. 2013, 9, E116-E123. [CrossRef]

20. De Oliveira, T.; Guégan, R.; Thiebault, T.; Milbeau, C.L.; Muller, F.; Teixeira, V.; Giovanela, M.; Boussafir, M. Adsorption of diclofenac onto organoclays: Effects of surfactant and environmental ( $\mathrm{pH}$ and temperature) conditions. J. Hazard. Mater. 2017, 323 Pt A, 558-566. [CrossRef]

21. Li, W.; Liu, D.; Zhang, H.; Correia, A.; Mäkilä, E.; Salonen, J.; Hirvonen, J.; Santos, H.A. Microfluidic assembly of a nano-in-micro dual drug delivery platform composed of halloysite nanotubes and a $\mathrm{pH}$-responsive polymer for colon cancer therapy. Acta Biomater. 2017, 48, 238-246. [CrossRef]

22. Gorrasi, G. Dispersion of halloysite loaded with natural antimicrobials into pectins: Characterization and controlled release analysis. Carbohydr. Polym. 2015, 127, 47-53. [CrossRef]

23. Lisuzzo, L.; Cavallaro, G.; Pasbakhsh, P.; Milioto, S.; Lazzara, G. Why does vacuum drive to the loading of halloysite nanotubes? The key role of water confinement. J. Colloid Interface Sci. 2019, 547, 361-369. [CrossRef] [PubMed]

24. Pinto-Junior, V.R.; Osterne, V.J.S.; Santiago, M.Q.; Correia, J.L.A.; Pereira-Junior, F.N.; Leal, R.B.; Pereira, M.G.; Chicas, L.S.; Nagano, C.S.; Rocha, B.A.M.; et al. Structural studies of a vasorelaxant lectin from Dioclea reflexa Hook seeds: Crystal structure, molecular docking and dynamics. Int. J. Biol. Macromol. 2017, 98, 12-23. [CrossRef]

25. Pinto-Junior, V.R.; Correia, J.L.; Pereira, R.I.; Pereira-Junior, F.N.; Santiago, M.Q.; Osterne, V.J.; Madeira, J.C.; Cajazeiras, J.B.; Nagano, C.S.; Delatorre, P.; et al. Purification and molecular characterization of a novel mannose-specific lectin from Dioclea reflexa hook seeds with inflammatory activity. J. Mol. Recognit. 2016, 29, 134-141. [CrossRef]

26. Ajatta, M.A.; Akinola, S.A.; Otolowo, D.T.; Awolu, O.O.; Omoba, O.S.; Osundahunsi, O.F. Effect of Roasting on the Phytochemical Properties of Three Varieties of Marble Vine (Dioclea reflexa) Using Response Surface Methodology. Prev. Nutr. Food Sci. 2019, 24, 468-477. [CrossRef] [PubMed]

27. Kazenel, M.R.; Debban, C.L.; Ranelli, L.; Hendricks, W.Q.; Chung, Y.A.; Pendergast, T.H.; Charlton, N.D.; Young, C.A.; Rudgers, J.A. A mutualistic endophyte alters the niche dimensions of its host plant. AoB Plants 2015, 7, plv005. [CrossRef] [PubMed]

28. Gupta, M.; Mazumder, U.K.; Pal, D.K.; Bhattacharya, S. Anti-steroidogenic activity of methanolic extract of Cuscuta reflexa roxb. stem and Corchorus olitorius Linn. seed in mouse ovary. Indian J. Exp. Boil. 2003, 41, 641-644.

29. Mazumder, U.K.; Gupta, M.; Pal, D.; Bhattacharya, S. Chemical and toxicological evaluation of methanol extract of Cuscuta reflexa Roxb. stem and Corchorus olitorius Linn. seed on hematological parameters and hepatorenal functions in mice. Acta Pol. Pharm. Drug Res. 2004, 60, 317-323.

30. Gupta, M.; Mazumder, U.K.; Pal, D.; Bhattacharya, S.; Chakrabarty, S. Studies on brain biogenic amines in methanolic extract of Cuscuta reflexa Roxb. and Corchorus olitorius Linn. seed treated mice. Acta Pol. Pharm. Drug Res. 2003, 60, $207-210$.

31. Gupta, M.; Mazumder, U.; Pal, D.; Bhattacharya, S. Onset of puberty and ovarian steroidogenesis following adminstration of methanolic extract of Cuscuta reflexa Roxb. stem and Corchorus olitorius Linn. seed in mice. J. Ethnopharmacol. 2003, 89, 55-59. [CrossRef]

32. Munge, B.S.; Stracensky, T.; Gamez, K.; DiBiase, D.; Rusling, J.F. Multiplex Immunosensor Arrays for Electrochemical Detection of Cancer Biomarker Proteins. Electroanalysis 2016, 28, 2644-2658. [CrossRef] [PubMed]

33. Nejadnik, M.R.; Deepak, F.L.; Garcia, C.D. Adsorption of Glucose Oxidase to 3-D Scaffolds of Carbon Nanotubes: Analytical Applications. Electroanalysis 2011, 23, 1462-1469. [CrossRef]

34. Szigeti, Z.; Vigassy, T.; Bakker, E.; Pretsch, E. Approaches to Improving the Lower Detection Limit of Polymeric Membrane Ion-Selective Electrodes. Electroanalysis 2006, 18, 1254-1265. [CrossRef]

35. de Oliveira, L.A.; Soares, R.O.; Buzzi, M.; Mourão, C.F.A.B.; Kawase, T.; Kuckelhaus, S.A.S. Cell and platelet composition assays by flow cytometry: basis for new platelet-rich fibrin methodologies. J. Biol. Regul. Homeost. Agents 2020, 34, 1379-1390. [PubMed]

36. Zhang, Y.; Zhang, X.; Zhang, J.; Sun, B.; Zhengfeng, Y.; Jinling, Z.; Liu, S.; Sui, G.; Yin, Z. Microfluidic chip for isolation of viable circulating tumor cells of hepatocellular carcinoma for their culture and drug sensitivity assay. Cancer Biol. Ther. 2016, 17, 1177-1187. [CrossRef]

37. Zhu, L.; Chen, Y.; Wei, C.; Yang, X.; Cheng, J.; Yang, Z.; Chen, C.; Ji, Z. Anti-proliferative and pro-apoptotic effects of cinobufagin on human breast cancer MCF-7 cells and its molecular mechanism. Nat. Prod. Res. 2018, 32, 493-497. [CrossRef]

38. Sargazi, S.; Kooshkaki, O.; Reza, J.Z.; Saravani, R.; Jaliani, H.Z.; Mirinejad, S.; Meshkini, F. Mild antagonistic effect of Valproic acid in combination with AZD2461 in MCF-7 breast cancer cells. Med J. Islam. Repub. Iran 2019, 33, 175-180. [CrossRef]

39. Mosmann, T. Rapid colorimetric assay for cellular growth and sur- vival: application to proliferation and cytotoxicity assays. J. Immunol. Methods 1983, 65, 55-63. [CrossRef]

40. Strober, W. Trypan blue exclusion test of cell viability. Curr. Protoc. Immunol. 2015, 111, A3. B.1-A3. B.3. [CrossRef] 
41. Owoseni, O.; Nyankson, E.; Zhang, Y.; Adams, S.J.; He, J.; McPherson, G.L.; Bose, A.; Gupta, R.B.; John, V.T. Surfactant-loaded halloysite clay nanotube dispersants for crude oil spill remediation. Ind. Eng. Chem. Res. 2015, 54, 9328-9341.

42. Bunaciu, A.A.; Udriştioiu, E.G.; Aboul-Enein, H.Y. X-Ray Diffraction: Instrumentation and Applications. Crit. Rev. Anal. Chem. 2014, 45, 289-299. [CrossRef] [PubMed]

43. Oladele Oladimeji, A.; Adebayo Oladosu, I.; Shaiq Ali, M.; Lateef, M. Dioclins A and B, new antioxidant flavonoids from Dioclea reflexa. Nat. Prod. Res. 2018, 32, 2017-2024. [CrossRef] [PubMed]

44. Wang, B.; Zhang, X.; Wang, C.; Chen, L.; Xiao, Y.; Pang, Y. Bipolar and fixable probe targeting mitochondria to trace local depolarization via two-photon fluorescence lifetime imaging. Analyst 2015, 140, 5488-5494. [CrossRef] [PubMed]

45. Kuralay, F.; Dükar, N.; Bayraml, Y. Poly-L-lysine Coated Surfaces for Ultrasensitive Nucleic Acid Detection. Electroanalytical 2018, 30, 1556-1565. [CrossRef] [PubMed]

46. Verhoeven, H.A.; van Griensven, L.J. Flow cytometric evaluation of the effects of 3-bromopyruvate (3BP) and dichloracetate (DCA) on THP-1 cells: a multiparameter analysis. J. Bioenergy Biomembr. 2012, 44, 91-99. [CrossRef] 